\title{
Sistem Pendukung Keputusan Penerima Program Keluarga Harapan (PKH) Menggunakan Metode Simple Additive Weighting
}

\author{
Intan Putri Pratiwi ${ }^{1}$, FX. Ferdinandus ${ }^{2}$, Arthur Daniel Limantara ${ }^{3}$ \\ ${ }^{1}$ Sekolah Tinggi Teknologi Cahaya Surya Kediri \\ ${ }^{2}$ Sekolah Tinggi Teknik Surabaya \\ ${ }^{3}$ Sekolah Tinggi Teknologi Cahaya Surya Kediri \\ E-mail: intanputripratiwi289@gmail.com,ferdi@stts.edu,arthur.limantara@gmail.com
}

\begin{abstract}
Abstrak
Penerimaan Bantuan Program Keluarga Harapan (PKH) adalah Rumah Tangga Sangat Miskin (RTSM) yang memiliki anggota keluarga yang terdiri dari anak usia 0-15 tahun (atau 15-18 tahun namun belum menyelesaikan pendidikan dasar) dan ibu hamil/nifas. Program Keluarga Harapan (PKH) memberikan bantuan tunai kepada RTSM dengan mewajibkan RTSM tersebut mengikuti persyaratan yang ditetapkan program, yaitu menyekolahkan anaknya disatuan pendidikan, dan melaksanakan kunjungan rutin ke fasilitas kesehatan bagi anak usia 0-6 tahun, ibu hamil dan ibu nifas. Adapun kriteria untuk mendapatkan Program Keluarga Harapan (PKH) adalah anak usia di bawah 6 tahun dan ibu hamil, anak usia SD/MI dan anak usia SMP/MTS. Untuk membantu menentukan dalam menetapkan seseorang yang layak menerima Program Keluarga Harapan(PKH) maka dibutuhkan sebuah sistem pendukung keputusan. Dengan adanya Sistem Pendukung Keputusan (SPK) ini di harapkan agar proses pengambilan keputusan dapat meminimalisir terjadinya salah sasaran yang sering timbul dalam proses penyeleksian warga yang ingin mendapatkan bantuan Program Keluarga Harapan (PKH). Metode yang digunakan adalah metode Simple Additive Weighting (SAW).
\end{abstract}

Kata Kunci : $P K H, R T S M, S A W$, dan $S P K$

\section{Pendahuluan}

\subsection{Latar Belakang Masalah}

Program Keluarga Harapan $(\mathrm{PKH})$ adalah suatu program pemberian bantuan sosial bersyarat kepada Keluarga Penerima Manfaat (KPM) yang ditetapkan sebagai keluarga penerima manfaat PKH. Program Perlindungan Sosial yang juga dikenal di dunia internasional dengan istilah Conditional Cash Transfers (CCT) ini terbukti cukup berhasil dalam menanggulangi kemiskinan yang dihadapi negara-negara tersebut, terutama masalah kemiskinan kronis. Secara khusus, tujuan PKH adalah meningkatkan akses dan kualitas pelayanan pendidikan dan kesehatan peserta $\mathrm{PKH}$, meningkatkan taraf pendidikan peserta $\mathrm{PKH}$, dan untuk meningkatkan status kesehatan dan gizi peserta PKH.

Seiring keberhasilan yang telah dicapai dan menurut pengamatan peneliti pada Program Keluarga Harapan(PKH) ini, masih ada permasalahan yang perlu dibenahi, salah satunya kesulitan dalam menentukan penerima Program Keluarga Harapan berdasarkan kriteria yang ada. Berdasarkan Peraturan Menteri Sosial Nomor 1 Tahun 2018 tentang Program Keluarga Harapan diterbitkan dengan pertimbangan untuk meningkatkan kualitas hidup keluarga miskin dan rentan melalui peningkatan aksesibilitas terhadap layanan kesehatan, pendidikan, dan kesejahteraan sosial.Karena saat ini banyak Program Keluarga Harapan (PKH) yang dinilai 
tidak tepat sasaran, dimana masih banyak orang yang seharusnya berhak, justru tidak mendapatkan dana bantuan tersebut. Hal ini berdampak ada subjektifitas di dalam penentuan peserta Program Keluarga Harapan (PKH), terutama jika beberapa calon peserta yang miskin atau kurang mampu memiliki tingkat kelayakan yang tidak jauh berbeda. Dalam hal ini sistem pendataan masih menggunakan data lama yang belum ter update sedangkan setiap tahun penduduk selalu mengalami perubahan pola status sosial dan pengolahan data masih secara manual.

Menghadapi hal tersebut, peneliti berdasarkan observasinya di Desa Joho ingin membuat program atau aplikasi yang dapat membantu mempermudah pihak kelurahan dalam menentukan penerima Program Keluarga Harapan $(\mathrm{PKH})$ untuk keluarga yang kurang mampu dengan membangun "Sistem Pendukung Keputusan Penerima Program Keluarga Harapan (PKH) Menggunakan Metode Simple Additive Weighting (SAW)". Pada penelitian ini akan diangkat suatu kasus yaitu mencari alternatif terbaik berdasarkan kriteriakriteria yang telah ditentukan dengan menggunakan metode Simple Additive Weighting (SAW).

\subsection{Tujuan Penelitian}

Adapun tujuan dari penelitian ini adalah membangun suatu aplikasi sistem pendukung keputusan untuk pemilihan penerima Program Keluarga Harapan (PKH). Adapun uraian dari tujuan penelitian sebagai berikut :

a. Merancang dan membuat sebuah Sistem Pendukung Keputusan Penerima Program Keluarga Harapan $(\mathrm{PKH})$ menggunakan metode Simple Additive Weighting (SAW)yang dapat mengolah kriteria dalam menentukan penerima PKH.

b. Menerapkan Simple Additive Weighting (SAW) untuk menentukan penerima Program Keluarga Harapan agar lebih efisien dan tepat sasaran.

\subsection{Pembatasan Masalah}

Berdasarkan rumusan masalah diatas agar pembahasan yang dirumuskan dapat lebih terfokus, maka permasalahan-permasalahan yang akan dibahas ke dalam ruang lingkup sebagai berikut :

a. Sistem Pendukung Keputusan ini hanya digunakan sebagai acuan perhitungan dalam penerimaan Program Keluarga Harapan (PKH).

b. Sistem ini tidak bertanggung jawab atas pengeluaran dana PKH ke masyarakat.

c. Metode yang digunakan hanya metode Simple Additive Weighting.

d. Aplikasi ini dirancang hanya menggunakan bahasa pemrograman PHP dengan database MySQL.

e. Data yang digunakan dalam Tugas Akhir ini hanya berasal dari Desa Joho Kecamatan Wates Kabupaten Kediri.

f. Kriteria-kriteria yang digunakan dalam penentuan penerima Program Keluarga Harapan yaitu :

- Kriteria luas rumah

- Kriteria status kepemilikan rumah

- Kriteria penghasilan

- Kriteria aset yang dimiliki

- Kriteria jenis dinding

- Kriteria jenis lantai

- Kriteria sumber air

- Kriteria ibu hamil / menyusui

- Kriteria lanjut usia / penyandang disabilitas berat

- Kriteria jumlah tanggungan 


\section{Landasan Teori}

\subsection{Program Keluarga Harapan}

Program Keluarga Harapan (PKH) adalah suatu program yamg memberikan bantuan tunai kepada Keluarga Penerima Manfaat (KPM), jika KPM tersebut memenuhi persyaratan yang terkait dengan upaya peningkatan kualitas Sumber Daya Manusia (SDM), yaitu pendidikan dan kesehatan. Sebagai sebuah program sosial bersyarat, PKH membuka akses keluarga miskin terutama ibu hamil dan anak untuk memanfaatkan berbagai fasilitas layanan kesehatan (faskes) dan fasilitas layanan pendidikan (fasdik) yang tersedia di sekitar masyarakat tersebut. Manfaat PKH juga mulai didorong untuk mencakup penyandang disabilitas dan lanjut usia dengan mempertahankan taraf kesejahteraan sosial sesuai dengan amanat konstitusi dan Nawacita Presiden RI.

\subsection{Sistem Pendukung Keputusan}

Sistem Pendukung Keputusan adalah bagian dari sistem informasi berbasis komputer yang dipakai untuk mendukung pengambilan keputusan dalam suatu organisasi atau perusahaan. Dapat juga dikatakan sebagai sistem komputer yang mengolah data menjadi informasi untuk mengambil keputusan dari masalah semi terstruktur yang spesifik.

\subsection{Simple Additive Weighting (SAW)}

Metode Simple Additive Weighting (SAW) sering dikenal dengan istilah metode penjumlahan terbobot. Konsep dasar metode Simple Additive Weighting (SAW) adalah mencari penjumlahan terbobot dari rating kinerja pada setiap alternatif pada semua atribut. Metode SAW membutuhkan proses normalisasi matriks keputusan (X) ke suatu skala yang dapat dibandingakan dengan semua rating alternatif yang ada (S. Kusumadewi, 2006)

\subsection{Flowchart}

Diagram alur dapat menunjukkan secara jelas arus pengendalian suatu algoritma, yakni melaksanakan suatu rangkaian kegiatan secara logis dan sistematis. Suatu diagram alur dapat memberi gambaran dua dimensi berupa simbol-simbol grafis. Masing-masing simbol telah ditetapkan lebih dahulu fungsi dan artinya. Simbol-simbol tersebut dipakai untuk menunjukkan berbagai kegiatan operasi dan jalur pengendalian. Arti khusus dari sebuah flowchart adalah simbol-simbol yang digunakan untuk menggambarkan urutan proses yang terjadi di dalam suatu program komputer secara sistematis dan logis. (Tata Sutabri, 2004)

\subsection{Entity Relationship Diagram}

Menurut Edhy Sutanta (2011) Entity Relationship Diagram adalah suatu pemodelan basisdata yang digunakan untuk menghasilkan skema konseptual untuk jenis/model data semantik sistem. Sistem memiliki basis data relasional, dan ketentuannya bersifat top-down. Diagram yang digunakan untuk menggambarkan model Entity-Relationship ini disebut Entity Relationship Diagram, ER diagram, atau ERD. ERD berfungsi untuk memodelkan struktur data dan hubungan antar data, untuk menggambarkannya digunakan beberapa notasi dan simbol.Pada dasarnya ada 3 komponen yang di gunakan dalam ERD, yaitu:

\section{a. Entity}

Entity merupakan objek yang mewakili sesuatu yang nyata dan dapat dibedakan dari sesutau yang lain. Simbolnya berbentuk persegi panjang. 
b. Atribut

Setiap entitas pasti mempunyai elemen yang disebut atribut yang berfungsi untuk mendeskripsikan karakteristik dari entitas tersebut. Isi dari atribut mempunyai sesuatu yang dapat mengidentifikasikan isi elemen satu dengan yang lain. Gambar atribut diwakili oleh simbol elips.

c. Hubungan / Relasi

Hubungan antara sejumlah entitas yang berasal dari himpunan entitas yang berbeda.

\subsection{Hypertext Preeprocecor (PHP)}

PHP merupakan singkatan dari Hypertext Preeprocecor yaitu bahasa pemrograman berbentuk script yang digunakan secara luas sebagai pembuatan suatu halaman website yang dinamis. Awal mulanya PHP adalah kependekan dari Personal Home Page yang diciptakan pertama kali oleh Rasmus Lerdof pada tahun 1995. Saat itu namanya masih Form Interpreted. Rasmus Lerdof selanjutnya merilis kode sumber ke khalayak umum (open source) sehingga dengan demikian banyak programmer tertarik untuk mengembangkan PHP ini.

\subsection{MySQL}

MySQL adalah salah satu jenis database server yang sangat terkenal. Kepopulerannya disebabkan MySQL menggunkaan SQL sebagai bahasa dasar untuk mengakses databasenya. Selain itu bersifat free (tidak perlu membayar untuk menggunakannya). MySQL termasuk jenis RDBMS (Relational Database Management System). Itulah sebabnya istilah seperti tabel, baris, dan kolom digunakan pada MySQL. Pada MySQL, sebuah database mengandung satu atau sejumlah table.

\section{Perancangan Sistem}

\subsection{Analisis Data}

Pada tahap sebelumnya dijelaskan mengenai metode analisis data dengan melakukan observasi secara langsung ke obyek penelitian untuk mengamati dan melakukan pencatatan secara sistematik terhadap gejala yang tampak pada subyek penelitian. Maka hasil dari analisis tersebut dapat disimpulkan bahwa penelitian ini akan sangat membantu proses pemberian bantuan. Berikut adalah tabel data statistik kependudukan Desa Joho:

Tabel 3.1. Perkembangan Kependudukan

\begin{tabular}{|l|c|c|}
\hline \multicolumn{3}{|c|}{ A. Jumlah Penduduk } \\
\hline Jumlah Penduduk & Laki-laki & Perempuan \\
\hline Jumlah penduduk tahun ini & 2687 orang & 2416 orang \\
\hline Jumlah penduduk tahun lalu & 2225 orang & 2720 orang \\
\hline Persentase perkembangan & $20.76 \%$ & $-11.18 \%$ \\
\hline
\end{tabular}

Tabel 3.2. Jumlah Keluarga

\begin{tabular}{|l|c|c|c|}
\hline \multicolumn{4}{|c|}{ B. Jumlah Keluarga } \\
\hline \multicolumn{1}{|c|}{ Jumlah } & $\begin{array}{c}\text { KK Laki- } \\
\text { laki }\end{array}$ & $\begin{array}{c}\text { KK Perempu- } \\
\text { an }\end{array}$ & Jumlah \\
\hline $\begin{array}{l}\text { Jumlah Kepala Keluarga tahun } \\
\text { ini }\end{array}$ & $1136 \mathrm{KK}$ & $262 \mathrm{KK}$ & $1398 \mathrm{KK}$ \\
\hline $\begin{array}{l}\text { Jumlah Kepala Keluarga tahun } \\
\text { lalu }\end{array}$ & $1525 \mathrm{KK}$ & $262 \mathrm{KK}$ & $1787 \mathrm{KK}$ \\
\hline Prosentase Perkembangan & $-25.51 \%$ & $0 \%$ & \\
\hline
\end{tabular}


Tabel 3.3. Ekonomi Masyarakat

\begin{tabular}{|l|c|}
\hline \multicolumn{2}{|c|}{ C.Ekonomi Masyarakat } \\
\hline $\begin{array}{l}\text { 1. Jumlah angkatan kerja (penduduk usia 18- } \\
\text { 56 tahun }\end{array}$ & 627 orang \\
\hline $\begin{array}{l}\text { 2. Jumlah penduduk usia 18-56 tahun yang } \\
\text { masih sekolah dan tidak bekerja }\end{array}$ & 118 orang \\
\hline $\begin{array}{l}\text { 3. Jumlah penduduk usia 18-56 tahun yang } \\
\text { menjadi ibu rumah tangga }\end{array}$ & 626 orang \\
\hline $\begin{array}{l}\text { 4. Jumlah penduduk usia 18-56 tahun yang } \\
\text { bekerja penuh }\end{array}$ & 215 orang \\
\hline $\begin{array}{l}\text { 5. Jumlah penduduk usia 18-56 tahun yang } \\
\text { bekerja tidak tentu }\end{array}$ & 265 orang \\
\hline $\begin{array}{l}\text { 6. Jumlah penduduk usia 18-56 tahun yang } \\
\text { cacat dan tidak bekerja }\end{array}$ & 15 orang \\
\hline $\begin{array}{l}\text { 7.Jumlah penduduk usia 18-56 tahun yang } \\
\text { cacat dan bekerja }\end{array}$ & 55 orang \\
\hline
\end{tabular}

Tabel 3.4. Kesejahteraan Keluarga

D. Kesejahteraan Keluarga

\begin{tabular}{|l|c|}
\hline 1. Jumlah keluarga prasejahtera & 460 keluarga \\
\hline 2. Jumlah keluarga sejahtera 1 & 625 keluarga \\
\hline 3. Jumlah keluarga sejahtera 2 & 311 keluarga \\
\hline 4. Jumlah keluarga sejahtera 3 & 250 keluarga \\
\hline 5.Jumlah keluarga sejahtera 3 plus & 84 keluarga \\
\hline 6. Total jumlah kepala keluarga & 1730 keluarga \\
\hline
\end{tabular}

\subsection{Analisis Kebutuhan Sistem}

Definisi kebutuhan sistem adalah faktor-faktor yang diperlukan oleh sistem dan diperlukan untuk perancangan perangkat lunak sehingga perangkat lunak tersebut sesuai dengan maksud dan tujuan pembuatan sistem tersebut.

\subsubsection{Kriteria}

\section{a. Rating Kecocokan kriteria dan Bobot}

Tabel 3.5. Tabel jenis kriteria

\begin{tabular}{|c|c|c|}
\hline Kriteria & $\begin{array}{c}\text { Jenis Varia- } \\
\text { bel }\end{array}$ & Bobot \\
\hline Penghasilan & Benefit & 2 \\
\hline Luas Rumah & Benefit & 1,5 \\
\hline Status Kepemilikan Rumah & Benefit & 1 \\
\hline Aset Yang Dimiliki & Benefit & 1,5 \\
\hline Jenis dinding & Benefit & 1 \\
\hline Jenis Lantai & Benefit & 1 \\
\hline Sumber air & Benefit & 0,5 \\
\hline Ibu hamil/menyusui & Cost & 0,5 \\
\hline Lanjut Usia/Penyandang Disabilitas & Cost & 0,5 \\
\hline Jumlah Tanggungan & Cost & 0,5 \\
\hline
\end{tabular}

\section{b. Menentukan tabel rating kecocokan kriteria}

- Kriteria Penghasilan

Tabel 3.6. Kriteria Penghasilan

\begin{tabular}{|c|c|c|}
\hline Kriteria & Klasifikasi & Nilai \\
\hline$>2.000 .000$ & Banyak & 2,5 \\
\hline $1.500 .000-$ & Cukup & 5 \\
\hline
\end{tabular}




\begin{tabular}{|c|c|c|}
\hline 2.000 .000 & & \\
\hline $0-1.500 .000$ & Sedikit & 7,5 \\
\hline
\end{tabular}

- Kriteria luas rumah

Tabel 3.7. Kriteria Luas Rumah

\begin{tabular}{|c|c|c|}
\hline Kriteria & Klasifikasi & Nilai \\
\hline$>500 \mathrm{~m} 2$ & Sangat Rendah & 1 \\
\hline $201-500 \mathrm{~m} 2$ & Rendah & 2,5 \\
\hline $101-200 \mathrm{~m} 2$ & Sedang & 5 \\
\hline $51-100 \mathrm{~m} 2$ & Tinggi & 7,5 \\
\hline $0-50 \mathrm{~m} 2$ & Sangat Tinggi & 10 \\
\hline
\end{tabular}

- Kriteria Status Kepemilikan Rumah

Tabel 3.8. Kriteria status kepemilikan rumah

\begin{tabular}{|c|c|c|}
\hline Kriteria & Klasifikasi & Nilai \\
\hline Milik Sendiri & Rendah & 2,5 \\
\hline Sewa & Sedang & 5 \\
\hline Menumpang & Tinggi & 7,5 \\
\hline
\end{tabular}

- Kriteria aset yang dimiliki

Tabel 3.9. Kriteria aset yang dimiliki

\begin{tabular}{|c|c|c|}
\hline Kriteria & Klasifikasi & Nilai \\
\hline$>30.000 .000$ & Banyak & 2,5 \\
\hline $\begin{array}{c}10.000 .000- \\
30.000 .000\end{array}$ & Sedang & 5 \\
\hline$<10.000 .000$ & Sedikit & 7,5 \\
\hline
\end{tabular}

- Kriteria jenis dinding

Tabel 3.10. Kriteria jenis dinding

\begin{tabular}{|c|c|c|}
\hline Kriteria & Klasifikasi & Nilai \\
\hline Bata & Rendah & 2,5 \\
\hline Kayu & Sedang & 5 \\
\hline Bambu & Tinggi & 7,5 \\
\hline
\end{tabular}

- Kriteria jenis lantai

Tabel 3.11. Kriteria jenis lantai

\begin{tabular}{|c|c|c|}
\hline Kriteria & Klasifikasi & Nilai \\
\hline Keramik & Rendah & 2,5 \\
\hline Semen & Sedang & 5 \\
\hline Tanah & Tinggi & 7,5 \\
\hline
\end{tabular}

- Kriteria sumber air

Tabel 3.12. Kriteria sumber air

\begin{tabular}{|c|c|c|}
\hline Kriteria & Klasifikasi & Nilai \\
\hline PDAM & Rendah & 2,5 \\
\hline Pompa air & Sedang & 5 \\
\hline Sumur & Tinggi & 7,5 \\
\hline
\end{tabular}

- Kriteria ibu hamil/menyusui

Tabel 3.13. Kriteria ibu hamil/menyusui

\begin{tabular}{|c|c|c|}
\hline Kriteria & Klasifikasi & Nilai \\
\hline Tidak Ada & Rendah & 2,5 \\
\hline Ada & Tinggi & 7,5 \\
\hline
\end{tabular}


- Kriteria Lanjut Usia/Penyandang Disabilitas

Tabel 3.14. Lanjut Usia/Penyandang Disabilitas

\begin{tabular}{|c|c|c|}
\hline Kriteria & Klasifikasi & Nilai \\
\hline Tidak ada & Rendah & 2,5 \\
\hline Ada & Tinggi & 7,5 \\
\hline
\end{tabular}

- Kriteria Jumlah Tanggungan

Tabel 3.15. Jumlah Tanggungan

\begin{tabular}{|c|c|c|}
\hline Kriteria & Klasifikasi & Nilai \\
\hline$>5$ & Banyak & 7,5 \\
\hline $2-5$ & Sedang & 5 \\
\hline 1 & Sedikit & 2,5 \\
\hline $\begin{array}{c}\text { Tidak Ada } \\
\text { Tanggun- } \\
\text { gan }\end{array}$ & Sangat Sedikt & 1 \\
\hline
\end{tabular}

\subsection{Spesifikasi Program}

Sistem pendukung keputusan ini memiliki rancangan program sebagai berikut :

a. Input

- Input data login

- Input data calon penerima PKH

- Input kriteria

b. Proses

- Proses data login

- Proses perhitungan Simple Additive Weighting

c. Output

- Laporan data penerima PKH

- Laporan hasil perhitungan

\subsection{Rancangan Sistem}

Bagian ini memuat hasil rancangan sistem, hasil rancangan sistem berupa Flowchart dan Entity Relationship Diagram(ERD). Hasil rancangan akan menggambarkan bagaimana sistem akan berjalan nantinya.

\subsubsection{Flowchart}

Alur sistem yang berjalan pada sistem penerimaan bantuan pada Desa Joho ditunjukkan pada gambar 3.1

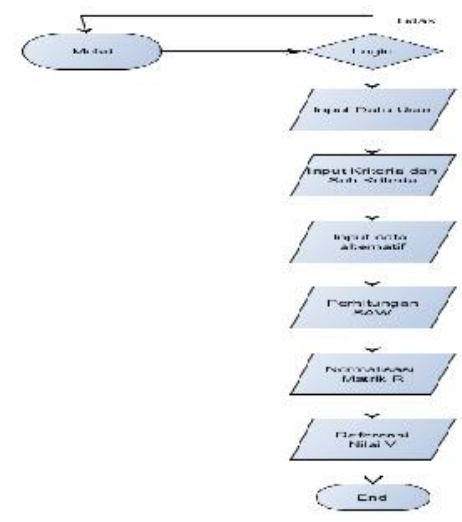




\subsubsection{Entity Relationship Diagram}

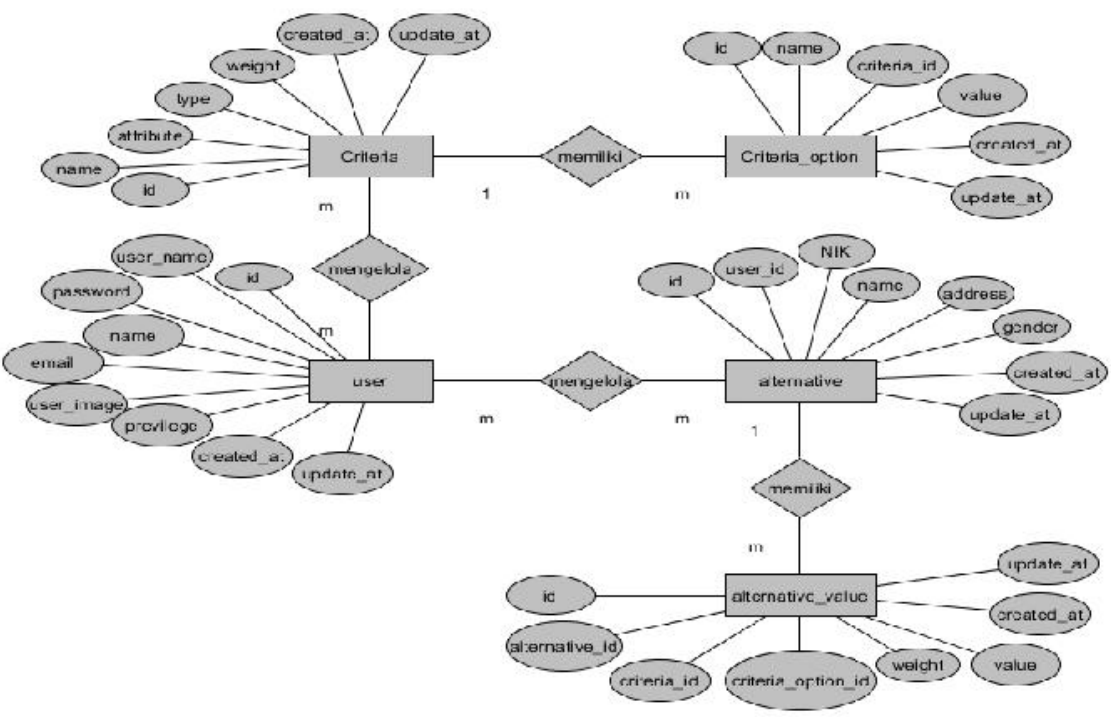

Gambar 3.2. Entity Relationship Diagram

\subsection{Rancangan Basis Data}

Sub bab ini berisi tentang rancangan tabel yang akan digunakan pada program penerima PKH ini.

Tabel 3.16 Tabel User

\begin{tabular}{|l|c|c|c|}
\hline \multicolumn{1}{|c|}{ Name } & Type & $\begin{array}{c}\text { Panjang } \\
\text { Field }\end{array}$ & Keterangan \\
\hline user_id & Int & 10 & Primary key \\
\hline username & varchar & 50 & \\
\hline password & varchar & 70 & \\
\hline Name & varchar & 50 & \\
\hline Email & varchar & 50 & \\
\hline user_img & varchar & 50 & \\
\hline Previlage & char & 25 & \\
\hline
\end{tabular}

\subsubsection{Tabel Criterias}

Tabel 3.17 Tabel Criterias

\begin{tabular}{|l|c|c|c|}
\hline \multicolumn{1}{|c|}{ Name } & Type & Panjang Field & Keterangan \\
\hline criteria_id & int & 10 & Primary key \\
\hline Name & varchar & 50 & \\
\hline attribute & varchar & 50 & \\
\hline type & varchar & 50 & \\
\hline weight & decimal & 7,2 & \\
\hline created_at & $\begin{array}{c}\text { timestam } \\
p\end{array}$ & & \\
\hline update_at & $\begin{array}{c}\text { timestam } \\
p\end{array}$ & & \\
\hline
\end{tabular}




\subsubsection{Tabel Criterias Options}

Tabel 3.18 Tabel Criterias

\begin{tabular}{|l|c|c|l|}
\hline \multicolumn{1}{|c|}{ Name } & Type & $\begin{array}{c}\text { Panjang } \\
\text { Field }\end{array}$ & Keterangan \\
\hline criteria_option_id & Int & 10 & Primary key \\
\hline criteria_id & Int & 10 & \\
\hline name & Varchar & 50 & \\
\hline value & Decimal & 7,2 & \\
\hline created_at & Timestamp & & \\
\hline update_at & Timestamp & & \\
\hline
\end{tabular}

\subsubsection{Tabel Alternatives}

Tabel 3.19 Tabel Criterias

\begin{tabular}{|l|c|c|l|}
\hline \multicolumn{1}{|c|}{ Name } & Type & $\begin{array}{c}\text { Panjang } \\
\text { Field }\end{array}$ & $\begin{array}{c}\text { Ket- } \\
\text { erangan }\end{array}$ \\
\hline alternative_id & Int & 10 & $\begin{array}{l}\text { Primary } \\
\text { key }\end{array}$ \\
\hline user_id & Int & 10 & \\
\hline nik & Int & 50 & \\
\hline Name & Varchar & 50 & \\
\hline address & Varchar & 50 & \\
\hline gender & Varchar & 10 & \\
\hline created_at & Timestamp & & \\
\hline update_at & Timestamp & & \\
\hline
\end{tabular}

\subsubsection{Alternative Value}

Tabel 3.20 Tabel Criterias

\begin{tabular}{|l|c|c|c|}
\hline \multicolumn{1}{|c|}{ Name } & Type & $\begin{array}{c}\text { Panjang } \\
\text { Field }\end{array}$ & Keterangan \\
\hline alternative_value_id & Int & 10 & Primary key \\
\hline alternative_id & Int & 10 & \\
\hline criteria_id & Int & 10 & \\
\hline criteria_option_id & Int & 10 & \\
\hline weight & decimal & 7,2 & \\
\hline value & varchar & 50 & \\
\hline created_at & timestamp & & \\
\hline update_at & timestamp & & \\
\hline
\end{tabular}

\section{Implementasi Dan Pembahasan}

\subsection{Interface / Antarmuka Pengguna}

\subsubsection{Form Login}

Form login digunakan admin, kepala desa dan warga untuk memasukkan username dan password untuk bisa masuk ke halaman utama admin, kepala desa, dan warga. Berikut adalah tampilan form login : 


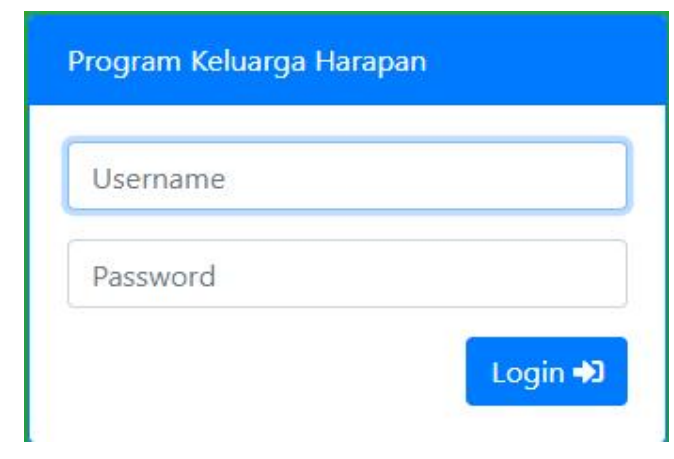

Gambar 4.1 Form Login

\subsubsection{Form Halaman Utama Admin}

Form halaman utama admin merupakan halaman yang akan ditampilkan pertama jika admin berhasil melakukan login. Berikut tampilan form halaman utama admin :

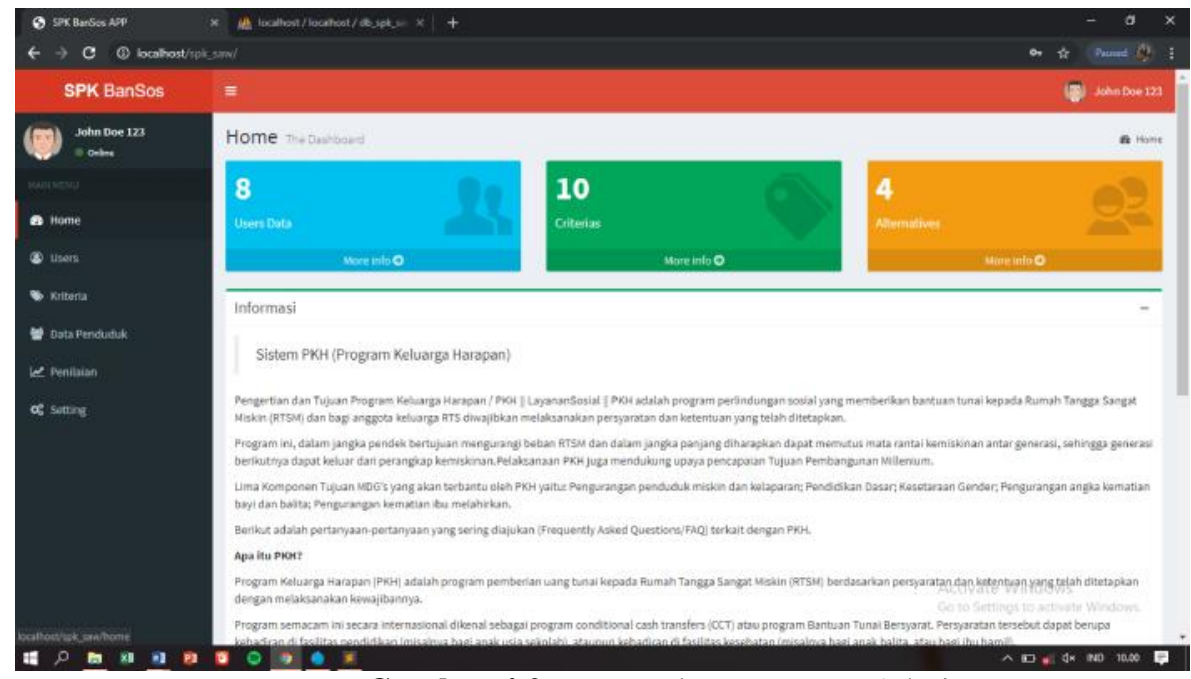

Gambar 4.2 Form Halaman Utama Admin

\subsubsection{Form Data User}

Form data user merupakan halaman yang akan menampilkan semua data user yang ada. Berikut tampilan form halaman data user :

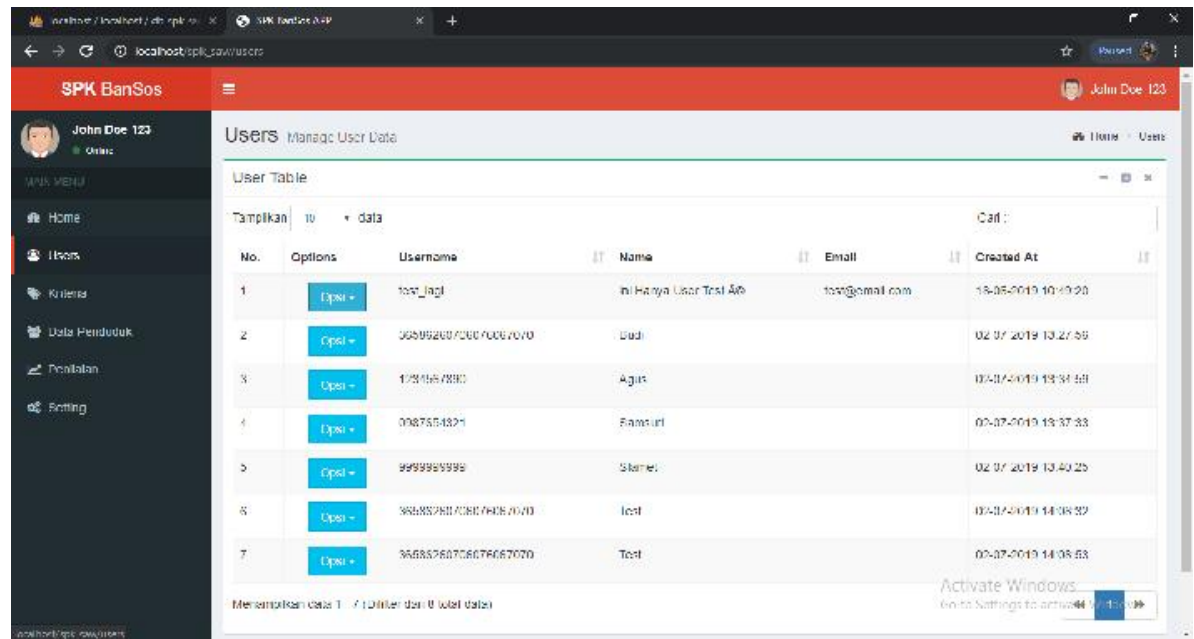

Gambar 4.3 Form Halamann Data User 


\subsubsection{Form Input User}

Form input user merupakan halaman yang menampilkan form untuk input data user baru. Berikut tampilan form input user :

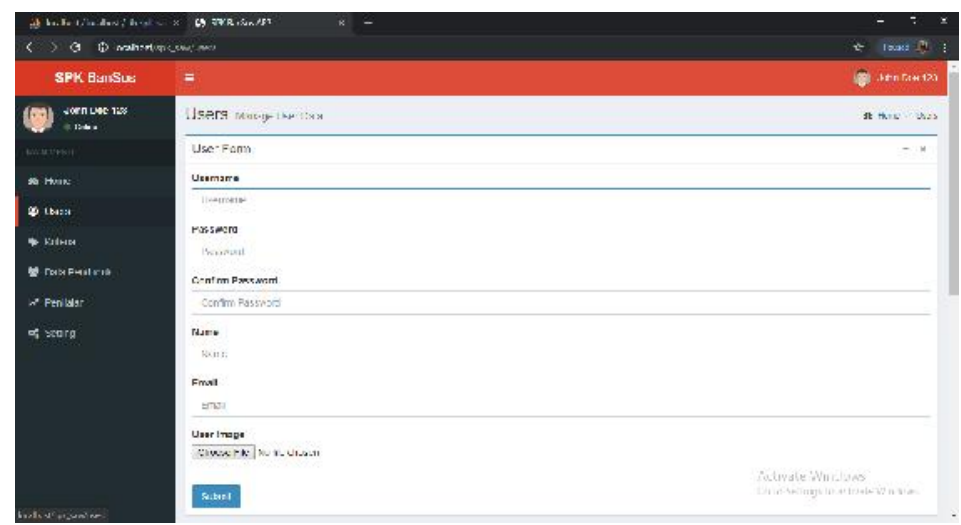

Gambar 4.4 Form Halaman Input User

\subsubsection{Form Data Kriteria}

Form data kriteria digunakan admin untuk melihat data kriteria yang sudah di inputkan oleh admin sebelumnya. Dan admin data mengedit dan menghapus data kriteria tersebut. Berikut tampilan form data kriteria :

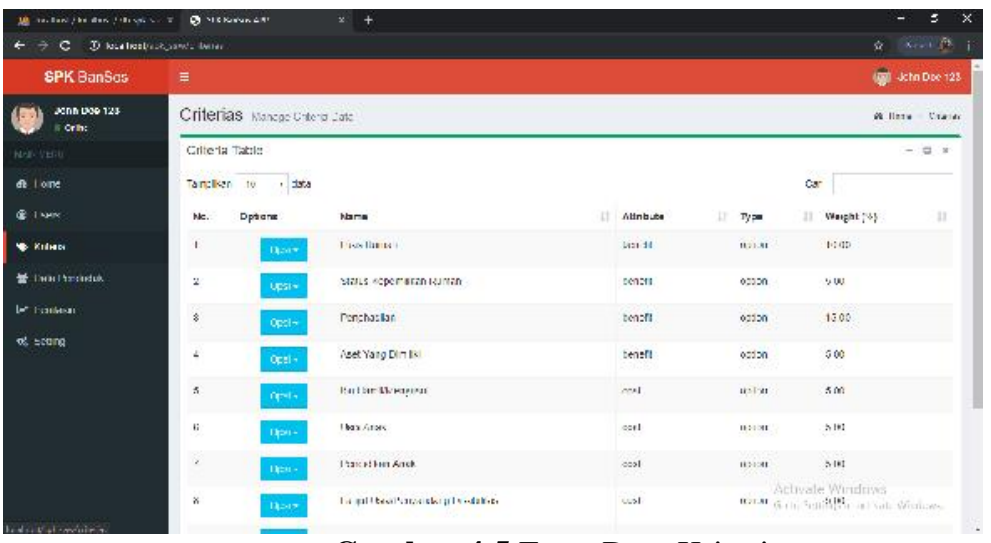

Gambar 4.5 Form Data Kriteria

\subsubsection{Form Input Kriteria}

Form input data kriteria digunakan admin untuk menginputkan data kriteria baru. Berikut tampilan form input data kriteria :

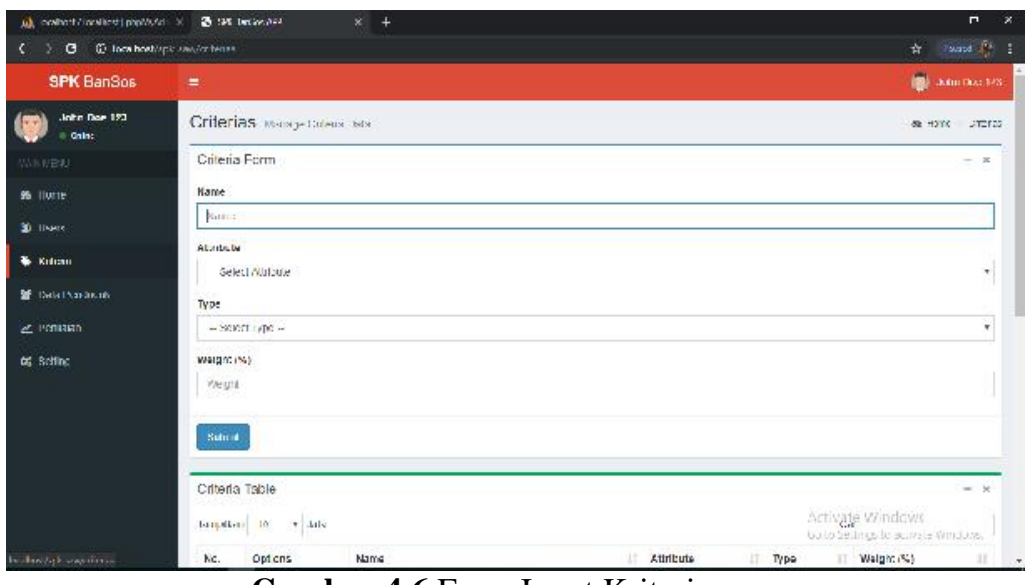

Gambar 4.6 Form Input Kriteria 


\subsubsection{Form Data Penduduk}

Form data penduduk digunakan admin untuk melihat data penduduk yag sudah di inputkan oleh admin sebelumnya. Dan admin dapat mengedit, menghapus serta mencetak data penduduk tersebut. Berikut tampilan form data penduduk :

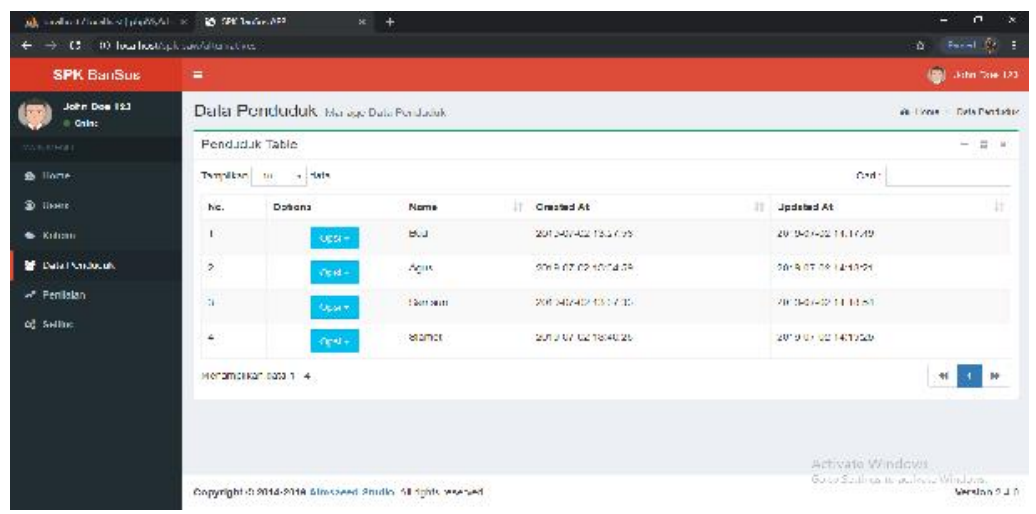

Gambar 4.7 Form Data Penduduk

\subsubsection{Form Input Data Penduduk}

Form input data penduduk digunakan admin untuk menginputkan data penduduk baru. Berikut tampilan form input data guru :

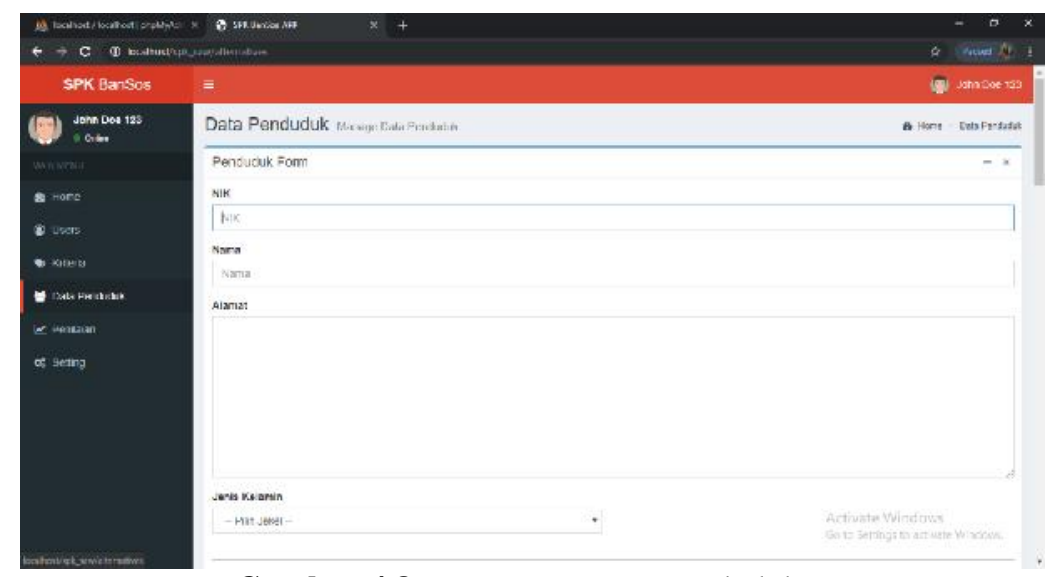

Gambar 4.8 Form Input Data Penduduk

\subsubsection{Form Halaman Hasil Penilaian SAW}

Form halaman penilaian ini menampilkan hasil dari penilaian calon penerima bantuan PKH. Berikut tampilan form halaman penilaian :

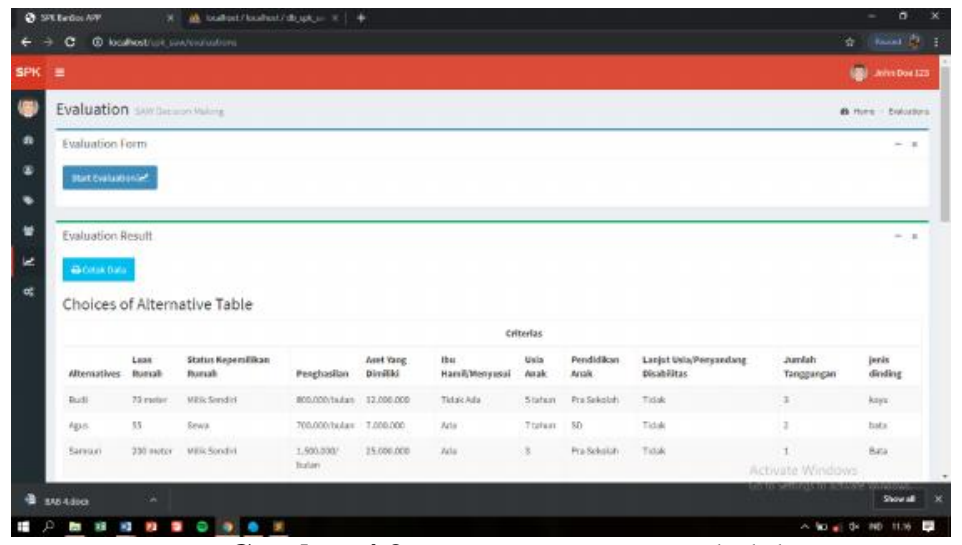

Gambar 4.9 Form Input Data Penduduk 


\subsubsection{Form Setting Nilai}

Form setting nilai ini digunakan admin untuk menginputkan nilai minimal untuk penilaian calon penerima PKH. Berikut tampilan form setting nilai :

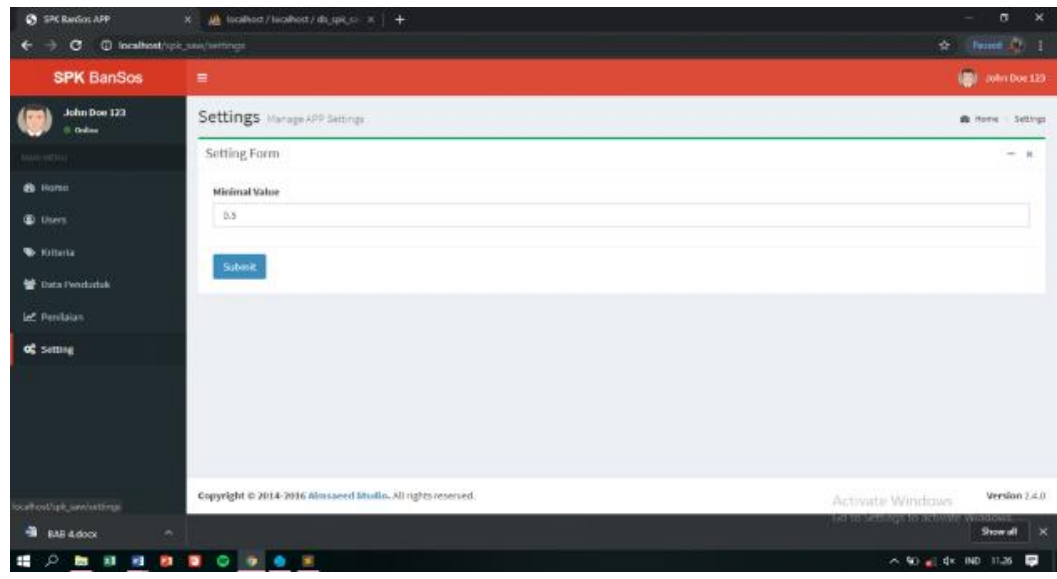

Gambar 4.10 Form Setting Nilai

\section{Kesimpulan Dan Saran}

\subsection{Kesimpulan}

Berdasarkan pembahasan implementasi dan evaluasi dari bab-bab sebelumnya serta teori yang ada, maka dapat ditarik kesimpulan sebagai berikut :

1. Metode Simple Additive Weighting dapat diterapkan dalam sistem pendukung keputusan penerima program keluarga harapan. Sistem ini digunakan sebagai acuan bagi pihak Desa Joho Kecamatan Wates untuk menentukan penerima bantuan.

2. Dengan sistem ini maka akan menjadikan kinerja pihak Desa Joho dalam menentukan bantuan menjadi lebih mudah dan resiko kecurangan menjadi lebih kecil.

\subsection{Saran}

Berdasarkan pengujian yang telah dilakukan pada sistem ini tentunya masih banyak kekurangan dan kelemahan yang terjadi sehingga perlu pengembangan lebih lanjut untuk kedepannya. Diharapkan nantinya akan ada pihak lain yang dapat mengembangkan penelitian ini menggunakan metode yang sama maupun yang lainnya.

\section{References}

[1] Anada, Kiki R. 2014. Sistem Pendukung Keputusan Untuk Menentukan Judul Skripsi Jurusan Teknik Informatika Komputer dengan Menggunakan Metode Simple Additive Weighting (SAW).Skripsi.S1 Teknik Informatika. Sekolah Tinggi Ilmu Komputer (STIKOM).

[2] Bonczek. 1980. Pendefinisian SPK sebagai sistem berbasis computer yang terdiri tiga komponen yang saling berinteraksi.

[3] Khoirunnisa,Atika N. 2014 . Sistem Pendukung Keputusan Penerima BLSM Di Desa Nepen Kecamatan Teras. Skripsi. S1 Teknik Informatika.Universitas Muhammadiyah. Surakarta.

[4] Khouf, Ridwan H. 2017. Sistem Pendukung Keputusan Kelayakan Calon Penerima Bantuan Bedah Rumah Di Kecamatan Sambirejo Dengan Menggunakan Metode Simple Additive Weighting. Skripsi. S1 Informatika. Universitas Muhammadiyah Surakarta.

[5] Kusrini,2007. Konsep dan Aplikasi Sistem Pendukung Keputusan, Yogyakarta : Penerbit Andi.

[6] Kusumadewi, S., Hartati, S., Harjoko, A., Wardoyo, R. 2006, Fuzzy Multi Atribute Decision Making Fuzzy MADM. Yogyakarta: Grahallmu. 
[7] McLeod Jr., Raymond. 1996. Sistem Informasi Manajemen : Studi Sistem Informasi Berbasis Komputer. Jakarta : PT Bhuana Ilmu Populer.

[8] Nugraha, Fajar. 2007. Sistem Pendukung Keputusan dengan metode Simple Additive Weighting (SAW) dalam Menejemen Aset. Yogyakarta : Graha Ilmu.

[9] Oetomo, Budi Sutedjo Dharma, 2002. Perencanaan dan Pembangunan Sistem Informasi, Andi, Yogyakarta.

[10] PKH. 2016. Mekanisme pelaksanaan. Jakarta: Kementrian Sosial.

[11] Suahasil Nazaram, S. K. R. 2013. Program Keluarga Harapan (PKH): Program Bantuan Dana Tunao Bersyarat di Indonesia. Jakarta: Kementrian Sosial.

[12] Sukerti.2014.Sistem Penunjang Keputusan Penerima Bantuan Desa di Kecamatan Klungkung dengan Metode SAW.Yogyakarta: UPN (Veteran).

[13] Sutabri, Tata. S.Kom,MM. 2004. Analisa Sistem Informasi. Yogyakarta : Edisi Pertama

[14] Sutanta, Edhy. 2011. Basis Data dalam Tinjauan Konseptual. Yogyakarta.

[15] Suundari, S., Taufik, Y., 2014. Sistem Pendukung Keputusan Penerima Pegawai Baru Dengan Menggunakan Metode Simple Additive Weighting (SAW), Jurnal Ilmiah SISFOTENIKA, Vol.4,No.2

[16] Wahyuni, Wanasari. 2018. Prioritas Penerima Bantuan Program Keluarga Harapan (PKH) Menggunakan Metode TOPSIS".Skripsi. S1 Teknik Informatika. Universitas Islam Negeri Maulana Malik Ibrahim. Malang

[17] Wijayanti,Wiwin.2014.SistemPendukungKeputusanPenentuanPenerimaBantuanLangsungTunai Di Kantor KepalaDesaNgringoDenganMenggunakanAlgoritma Simple Additive Weighting (SAW).JurnalTIKomSiN.ISSN : 2338-4018,2014.

[18] S. W. Mudjanarko, S. Winardi, and A. D. Limantara, "Pemanfaatan internet of things (iot) sebagai solusi manejemen transportasi kendaraan sepeda motor," Pros. Semin. Nas. Apl. Teknol. Prasarana Wil. X, no. August, 2017.

[19] A. D. Triono et al., "Utilization of Pedestrian Movement on the Sidewalk as a Source of Electric Power for Lighting Using Piezoelectric Censors," in 2018 3rd IEEE International Conference on Intelligent Transportation Engineering, ICITE 2018, 2018.

[20] A. D. Limantara, L. D. Krisnawati, S. Winardi, and S. W. Mudjanarko, "Solusi Pengawasan Kebijakan Mengatasi Kemacetan Jalan dan Parkir Kota Berbasis Internet Cerdas," Semin. Nas. Teknol. dan Rekayasa Inf., no. November, pp. 1-6, 2017.

[21] A. D. Limantara, S. Winarto, and S. W. Mudjanarko, "Sistem Pakar Pemilihan Model Perbaikan Perkerasan Lentur berdasarkan Indeks Kondisi Perkerasan (Pci)," Semin. Nas. dan Teknol. Fak. Tek. Universtas Muhammadiyah Surakarta, no. November, pp. 1-2, 2017.

[22] A. D. Limantara, Y. Cahyo, S. Purnomo, and S. W. Mudjanarko, "Pemodelan Sistem Pelacakan LOT Parkir Kosong Berbasis Sensor Ultrasonic Dan Internet Of Things ( IOT ) Pada Lahan Parkir Diluar Jalan,” Semin. Nas. Sains dan Teknol., vol. 1, no. 2, pp. 1-10, 2017.

[23] A. Alimudin, A. Z. Falani, S. W. Mudjanarko, and A. D. Limantara, "Analisis Pengaruh Penerapan Perspektif Balanced Scorecard Terhadap Peningkatan Kinerja UMKM,” Ekonika J. Ekon. Univ. kadiri, vol. 4, no. 1, p. 1, 2019. 